\title{
Intercity Bus Service Funding and Assessment Methodology
}

\author{
Zhirui Ye, Southeast University \\ David Kack, Jaydeep Chaudhari, and Levi Ewan, Montana State University
}

\begin{abstract}
The Federal Transit Administration (FTA)'s 5311(f) program requires that 15 percent of 5311 program funds given to a state be used to develop and support intercity bus (ICB) service. This 15 percent can be waived if the governor certifies that the ICB needs are being met within the state. This certification became harder to justify when FTA began requiring a more stringent consultation process before certification could be given. The objectives of this study are to learn about current practices of ICB service funding mechanisms, funds prioritization, and determination processes and strategies that promote ICB service. An assessment methodology for Montana was developed to determine whether ICB needs are being adequately met and how to allocate funds to support service. The results of this study will be valuable to other states considering developing methodologies for certification and funding allocation purposes.
\end{abstract}

\section{Introduction}

The Federal Transit Administration (FTA) defines intercity bus (ICB) service as:

regularly scheduled bus service for the general public that operates with limited stops over fixed routes connecting two or more urban areas not in close proximity, that has the capacity for transporting baggage carried by passengers, and that makes meaningful connections with scheduled ntercity bus service to more distant points, if such service is available (FTA 2007). 
Due to deregulation of ICB, an increase in personal automobile ownership, competition from airlines and Amtrak, and high operating costs, the ICB industry abandoned numerous unprofitable routes across the United States in the last five decades, leaving nearly 15,000 communities disconnected. ICB operations, however, have been recovering since 2006. The increase is related to federal transit laws, particularly Title 49 United States Code 5311(f), which support the development and revitalization of ICB transportation (FTA 2007). ICB service funding from FTA's Section 5311(f) program (Non-Urbanized Intercity Bus Formula Program) is a part of a larger program known as Formula Grants for Other than Urbanized Areas. The 5311 program provides state funding to support public transportation in areas with populations less than 50,000 . Goals of the program include:

1) enhancing the access of non-urbanized populations to health care, shopping, education, employment, public services, and recreation

2) assisting in the maintenance, development, improvement, and use of public transportation in non-urbanized areas

3) coordinating programs and services to facilitate the most efficient use of passenger service transportation funds in non-urbanized areas

4) assisting in the development and support of intercity bus transportation

5) providing for the participation of private transportation providers in nonurbanized transportation (FTA 2010)

The 5311(f) program requires that 15 percent of the total 5311 program funds given to a state be used to "carry out a program to develop and support intercity bus transportation" (FTA 2007). This 15 percent can be used elsewhere if the governor certifies that the ICB needs are being met within the state. Prior to the Safe, Accountable, Flexible, and Efficient Transportation Equity Act: A Legacy for Users (SAFETEA-LU) of 2005, governors often certified that their ICB needs were being met in order to use the funds in other areas. This certification became harder to justify after SAFETEA-LU because it required a more stringent consultation process before certification could be given. Hence, it is critical for states to develop assessment methodologies that can be used periodically to determine whether or not ICB needs are being adequately met and how to allocate funds to support ICB service. Moreover, it is important to learn about state funding practices in response to the 5311(f) program, which can be valuable for promoting ICB services in nonurbanized areas. 
This study explored the mechanisms of ICB funding currently used by states. After a literature review was conducted, a survey to Departments of Transportation (DOTs) in selected rural states was carried out to further explore ICB funding mechanisms, funds prioritization, and determination processes, the proportion of 5311 funds used for ICB services, and strategies to promote ICB services. An assessment methodology for ICB service needs was developed for the rural state of Montana. This methodology can be periodically used to determine whether or not ICB service needs are being adequately met. The results of this study will be valuable to other states considering developing their own methodologies for certification and funding allocation purposes.

\section{Review of Intercity Bus Service Funding}

There are two primary methods for funding ICB service. The first is a grant funding process, which involves ICB providers applying for funding and state DOT personnel determining which applicants receive it. lowa uses this method with the following priority rankings:

1) providing existing ICB service (award $\$ 0.20 /$ mile)

2) adding new feeder routes from non-urban communities (award $\$ 0.50 /$ mile for new service, $\$ 0.20 /$ mile for duplicate routes)

3) increasing public awareness and marketing (award case-by-case)

4) upgrading equipment and facilities such as ADA accessibility equipment (award case-by-case) (Lindly 2009)

Colorado, Minnesota, and Pennsylvania DOT programs also provide assistance in the form of grants to eligible applicants (KFH Group 2010).

A different approach to ICB service funding is a system that more closely resembles a bid process. State DOT personnel identify potential ICB service routes in need of upgrades, then issue a request to qualified bidders. The bidders propose a compensation rate for providing services on the identified routes. Washington State DOT (WSDOT) uses the bid method. After WSDOT staff identifies a route in need of service, they issue a Request for Proposal (RFP) and ask that bidders provide their qualifications, price, and experience and a proposed business plan. The bids are reviewed by a panel consisting of WSDOT staff, a Washington Utilities and Transportation Commission (WUTC) representative, local (non-bidding) transit operators, and representatives of the non-bidding private bus industry (KFH Group 2007). 
Other states, such as California and Oregon, are not limited to one funding approach. Caltrans provides ICB assistance with grants, RFPs, and a mixture of both approaches. In Oregon, funding is provided through a grant under the discretionary program, while an RFP approach is used under a pilot project for service on particular corridors that were identified by an Oregon DOT needs study (KFH Group 2010).

ICB service funds are used for different purposes depending on an individual state's funding priorities, as noted in its ICB plans. Aside from the 5311(f) program, a number of states have their own funds for subsidizing ICB services (KFH Group 2002). State funds allow more flexibility in funding projects than is possible with the federal program and its rules and regulations. Many local funds are used by intercity program sponsors to support ICB services (KFH 2002). In general, however, state and local funds are used as the "local match" that is required under the 5311(f) program.

\section{State of the Practice in ICB Service Funding}

A survey was distributed to DOT public transportation directors in 10 statesColorado, Nevada, New Mexico, North Dakota, Oregon, South Dakota, Texas, Utah, Washington, and Wyoming - to learn about current funding practices. These states were selected in consultation with the Montana Department of Transportation and were selected based on their rural nature and other similarities to Montana. Nine of these 10 state officials responded to the survey (a $90 \%$ response rate). Survey results of funding practices in the nine states that responded are summarized in Table 1.

When the states were asked about their current use of ICB funds, six of the nine respondents reported that their states used 15 percent of the 5311(f) for ICB service as directed by federal statute. Wyoming stated it used 20 percent of its 5311(f) for ICB service in FY 2011. Wyoming's practice had been to set aside 15 percent of 5311(f) for ICB service; however, from 2006 to 2010, there was a lack of sufficient projects to use the full amount allocated for this use. In addition, Wyoming allocated funds to rural feeder services and a regional commercial bus service (capital funds). Colorado has steadily increased its 5311(f) percentage from 6 percent to 14.8 percent in the past 6 years. South Dakota certified that ICB service needs were being met and used a portion of the 15 percent toward ICB service. The exact percentage used was unclear, but approximately 4 percent was reported to be allocated to "ICB provider(s)." 
Table 1. Summary of Funding Practices in Rural States

\begin{tabular}{|c|c|c|c|}
\hline State & $\begin{array}{c}\text { Proportion } \\
\text { of } 5311 \\
\text { Funds }^{\mathrm{a}} \\
\end{array}$ & $\begin{array}{c}\text { ICB } \\
\text { Funding } \\
\text { Mechanism }\end{array}$ & $\begin{array}{l}\text { ICB Funds Prioritization and } \\
\text { Determination Process }\end{array}$ \\
\hline Colorado & $14.8 \%$ & $\begin{array}{l}\text { Grantor/ } \\
\text { grantee } \\
\text { system }\end{array}$ & $\begin{array}{l}\text { Funding allocation based on a statewide and } \\
\text { regional ICB study. Process: } \\
\text { a) ICB providers submit proposals. } \\
\text { b) ICB Advisory Committee reviews and scores } \\
\text { applications. } \\
\text { c) CDOT Division of Transit and Rail determines } \\
\text { which projects to fund and at what level. }\end{array}$ \\
\hline New Mexico & $15 \%$ & N/A & $\mathrm{N} / \mathrm{A}$ \\
\hline $\begin{array}{l}\text { North } \\
\text { Dakota }\end{array}$ & $15 \%$ & $\begin{array}{l}\text { Grantor/ } \\
\text { grantee } \\
\text { system }\end{array}$ & $\begin{array}{l}2011 \text { is NDDOT's first year using ICB grant applica- } \\
\text { tion process. Funding allocation prioritized based } \\
\text { on identified routes and needs listed by providers. }\end{array}$ \\
\hline Oregon & $15 \%$ & $\begin{array}{l}\text { Both (grant- } \\
\text { or/grantee } \\
\text { and RFP/bid } \\
\text { systems) }\end{array}$ & $\begin{array}{l}15 \% \text { as required by FTA formula. Process: } \\
\text { a) Discretionary Grant Program; b) contract ICB } \\
\text { service based on service gap analysis; c) Transit In- } \\
\text { formation Investments based on information gaps. }\end{array}$ \\
\hline $\begin{array}{l}\text { South } \\
\text { Dakota }\end{array}$ & $4 \% *$ & $\begin{array}{l}\text { Grantor/ } \\
\text { grantee } \\
\text { system }\end{array}$ & $\begin{array}{l}\text { ICB provider included in yearly reviews for what } \\
\text { projects can be funded at what amounts. Process: } \\
\text { a) ICB providers submit budget requests; b) SDDOT } \\
\text { reviews budget requests; c) determinations made. }\end{array}$ \\
\hline Texas & $15 \%$ & $\begin{array}{l}\text { Grantor/ } \\
\text { grantee } \\
\text { system }\end{array}$ & $\begin{array}{l}15 \% \text { as required by FTA formula. Process: a) Submit- } \\
\text { ted proposals scored by interagency team, funding } \\
\text { amounts recommended; b) funds awarded by Texas } \\
\text { Transportation Commission. }\end{array}$ \\
\hline Utah & $15 \%$ & $\begin{array}{l}\text { RFP/bid } \\
\text { system }\end{array}$ & $\begin{array}{l}15 \% \text { as required by FTA formula if sufficient proj- } \\
\text { ects available. Funding allocation based on previous } \\
\text { ICB study that identified areas for ICB service. }\end{array}$ \\
\hline Washington & $15 \%$ & $\begin{array}{l}\text { RFP/bid } \\
\text { system }\end{array}$ & $\begin{array}{l}15 \% \text { as required by FTA formula. Funding allocation } \\
\text { based on analysis of } 2007 \text { Statewide Rural Intercity } \\
\text { Bus Plan. Process: a) Review of state demographics } \\
\text { to identify areas with mobility needs; b) based on } \\
\text { demographic analysis, routes to towns where con- } \\
\text { nections to national intercity network can be made } \\
\text { are identified and prioritized for funding. }\end{array}$ \\
\hline Wyoming & $20 \%$ & N/A & N/A \\
\hline
\end{tabular}

*South Dakota noted that they also fund rural feeder services and "Jefferson Lines" for an amount that was not specified in the response. 
While the previous question asked about current funding practices, the next question asked states to describe the process used to determine the amount of funds allocated to ICB service. Three states (Texas, Washington, and Oregon) reported they used 15 percent of $5311(\mathrm{f})$ for ICB as required by the FTA formula, while Utah DOT stated it used 15 percent assuming sufficient projects/services were available to use the funds. In South Dakota and Colorado, ICB providers first submitted applications (budget requests) that were reviewed to determine which projects to fund. Colorado used an ICB Advisory Committee comprising members from the Transit and Rail Division, the Regional Transportation District, and the Colorado Public Utilities Commission to review and score applications, which were then considered for funding based on the scoring results. North Dakota implemented its ICB grant application process beginning in $\mathrm{FY}$ 2011. Prior to that, it used historical data and the judgment of a solitary transit-focused DOT employee to decide which projects to fund. Two other states (New Mexico and Wyoming) did not respond to this question.

The survey asked a question concerning prioritization of funding allocations. Three states (Utah, Colorado, and Washington) reported that they prioritized the funding based on results from statewide and regional ICB studies. Utah indicated it funded a shared route with Colorado, and the remaining funding was allocated based on an RFP and a recent statewide ICB study that identified areas for ICB service. In Washington, mobility needs were first identified using demographics, then routes were identified with towns where connections to the national intercity network could be made. Colorado indicated a preference to continue funding existing routes before initiating new routes. Texas DOT used an "interagency team" to review and score submitted proposals and prioritize funding. Oregon funded projects first through a Discretionary Grant Program, then provided ICB funds based on a "service gap analysis" and provided transit information investments based on identified "information gaps." South Dakota reported that its presumably sole "ICB provider" was involved in yearly reviews to help prioritize allocation of funds. North Dakota stated it prioritized funding based on routes and needs prioritized by ICB providers. Two states did not respond.

The states were asked a question regarding how they awarded funds to potential ICB providers. Options included "a grantor/grantee system with potential services applied for similar to a grant" or "an RFP/bid system with potential projects identified by the DOT, then issuing an RFP on which service providers then bid," or "a different system." Results showed that four states (Colorado, North Dakota, South Dakota and Texas) 
used a grant-type system and two states (Utah and Washington) used an RFP/bid system. Oregon reported that both processes were used. Two states did not respond.

\section{Promoting ICB Service}

In the survey, the states were asked if any state agency actively promoted ICB service. Seven of the nine states responded to the question, with six states reporting that they did actively promote ICB services. Colorado noted that it frequently issues press releases on new ICB routes, stations, schedules, equipment, and other information. It also pays for newspaper advertising of routes and schedules and is currently developing a transit map that will include ICB service. Washington "promotes ICB service at conferences, both regionally and nationally" and also contractually expects the ICB providers to maintain websites and advertise through radio, television, and newspaper media. Washington also offers online ticketing and reservation capabilities. Other states said their actions were minimal but included website information with routes and schedules. Information about the strategies used to promote ICB service is summarized in Table 2. Colorado and Washington indicate that ICB ridership in their states has increased in the last two years.

Table 2. Summary of Strategies in Promoting ICB Service

\begin{tabular}{|c|c|}
\hline State & Strategies in Promoting ICB Services \\
\hline Colorado & $\begin{array}{l}\text { a) Frequently issues press releases on new ICB information. } \\
\text { b) Pays for newspaper advertising of routes and schedules. } \\
\text { c) Is currently developing a transit map. }\end{array}$ \\
\hline $\begin{array}{l}\text { North } \\
\text { Dakota }\end{array}$ & First year (2011) in promoting ICB service. \\
\hline Oregon & $\begin{array}{l}\text { a) Has both printed and electronic ICB service schedules. } \\
\text { b) Maintains websites, including Trip Check-TO transit information (http://www. } \\
\text { tripcheck.com/rtp-to/cityCounty/cityCountySearch .aspx) and Oregon-POINT } \\
\text { service (www.oregon-point.com). }\end{array}$ \\
\hline $\begin{array}{l}\text { South } \\
\text { Dakota }\end{array}$ & $\begin{array}{l}\text { a) Has press releases when a new rural transit provider may become a feeder service. } \\
\text { b) Supports websites. }\end{array}$ \\
\hline Texas & Marketing is an eligible expense for project funded through 5311(f). \\
\hline Utah & Does not actively promote ICB services. \\
\hline Washington & $\begin{array}{l}\text { a) Promotes ICB service at regional and national conferences. } \\
\text { b) Promotes programs through cooperative assistance (providing documents) to } \\
\text { other states. } \\
\text { c) Each ICB route is named after products produced in the particular part of the } \\
\text { state (e.g., Gold Line, Grape Line, Apple Line). }\end{array}$ \\
\hline
\end{tabular}




\section{Assessment of Intercity Bus Service Needs in Montana}

Although many states have their own ICB funding prioritization process, there is still a lack of information on the development of assessment methodologies that can be used to periodically determine whether or not ICB needs are being adequately met and how to allocate funds to support ICB service. Montana was used to develop a methodology for the assessment of ICB service needs and funding allocation.

\section{Assessment Methodology}

As a rural state, national/major ICB services in Montana are provided in the areas along Interstates 90 and 15 and US Highway 93 north of Missoula. A large geographic area of the state does not have ICB services. An analysis indicates that approximately 45 percent of Montanans (436,799 people) live in cities served by national/major ICB services, including 8 of the 10 largest cities in the state, as shown in Table 3. Only three cities in Montana exceed this threshold and are considered urban: Billings, Missoula, and Great Falls (U.S. Census Bureau 2009).

Based on existing ICB funding practices in Montana and other rural states, a method combining an annual process and a triennial consultation process was developed, as shown in Figure 1. The process includes five components: review of existing ICB services, support for existing services, determination of funding, analysis of potential new services, and funding for new services. The first three steps are used as an annual process to support existing ICB services, and the triennial process is to determine funding for new services.

\section{Annual Process}

The proposed annual process begins with review and evaluation of the performance of existing ICB services in order to assess to what degree the ICB projects have achieved their goals. The Montana Department of Transportation (MDT) reviews existing public transportation services within the state through the use of information obtained in quarterly reports submitted by providers. The current review analyzes factors including ridership, mileage, and the capital needs of the ICB providers.

Based on review results, decisions regarding support for existing services fall into two categories: 1) services to be cut or to receive reduced funding, and 2) services to receive level or increased funding. Services that have decreasing ridership may receive reduced funding in the next fiscal year or could be completely cut, depending upon ridership levels. Alternatively, services with increasing ridership may receive additional funding from MDT. It is recommended that MDT continues to use its current evaluation practices for these initial steps. 
Table 3. Cities/Towns with ICB Service in Montana ${ }^{\mathrm{a}}$

\begin{tabular}{|l|c|c|c|c|c|}
\hline \multirow{2}{*}{ City/Town } & \multicolumn{2}{|c|}{$\mathbf{2 0 0 9}$ Population ${ }^{\mathbf{b}}$} & \multirow{2}{*}{ City/Town } & 2009 Population \\
\cline { 2 - 3 } \cline { 6 - 6 } & Estimate & Rank $^{c}$ & & Estimate & Rank \\
\hline Billings & 105,845 & 1 & Columbus & 2,039 & 34 \\
\hline Missoula & 68,876 & 2 & Ronan & 1,999 & 36 \\
\hline Great Falls & 59,366 & 3 & Three Forks & 1,970 & 37 \\
\hline Bozeman & 39,282 & 4 & Forsyth & 1,865 & 39 \\
\hline Butte-Silver Bow & 32,268 & 5 & Big Timber & 1,740 & 41 \\
\hline Helena & 29,939 & 6 & Manhattan & 1,677 & 43 \\
\hline Kalispell & 21,640 & 7 & W. Yellowstone & 1,502 & 46 \\
\hline Whitefish & 8,400 & 10 & Boulder & 1,475 & 47 \\
\hline Belgrade & 8,192 & 11 & Whitehall & 1,191 & 52 \\
\hline Miles City & 8,123 & 12 & St. Ignatius & 807 & 65 \\
\hline Livingston & 7,380 & 13 & Cascade & 770 & 67 \\
\hline Laurel & 6,750 & 14 & Bridger & 736 & 68 \\
\hline Polson & 5,231 & 17 & Terry & 567 & 79 \\
\hline Glendive & 4,628 & 20 & Wibaux & 480 & 82 \\
\hline Dillon & 4,226 & 21 & Drummond & 322 & 94 \\
\hline Hardin & 3,532 & 22 & Hysham & 233 & 100 \\
\hline Deer Lodge & 3,517 & 24 & Lima & 231 & 101 \\
\hline Total Population with Service & & & 436,799 \\
\hline
\end{tabular}

a ICB Service, for this purpose, is defined as listed stops on websites of regional bus service providers Greyhound, Rimrock Stages/Trailways and Salt Lake City Express.

${ }^{b}$ Montana 2009 population estimate 974,989.

' Ranking based on 129 cities/towns recognized by U.S. Census.

Source: (U.S. Census Bureau, 2009) 


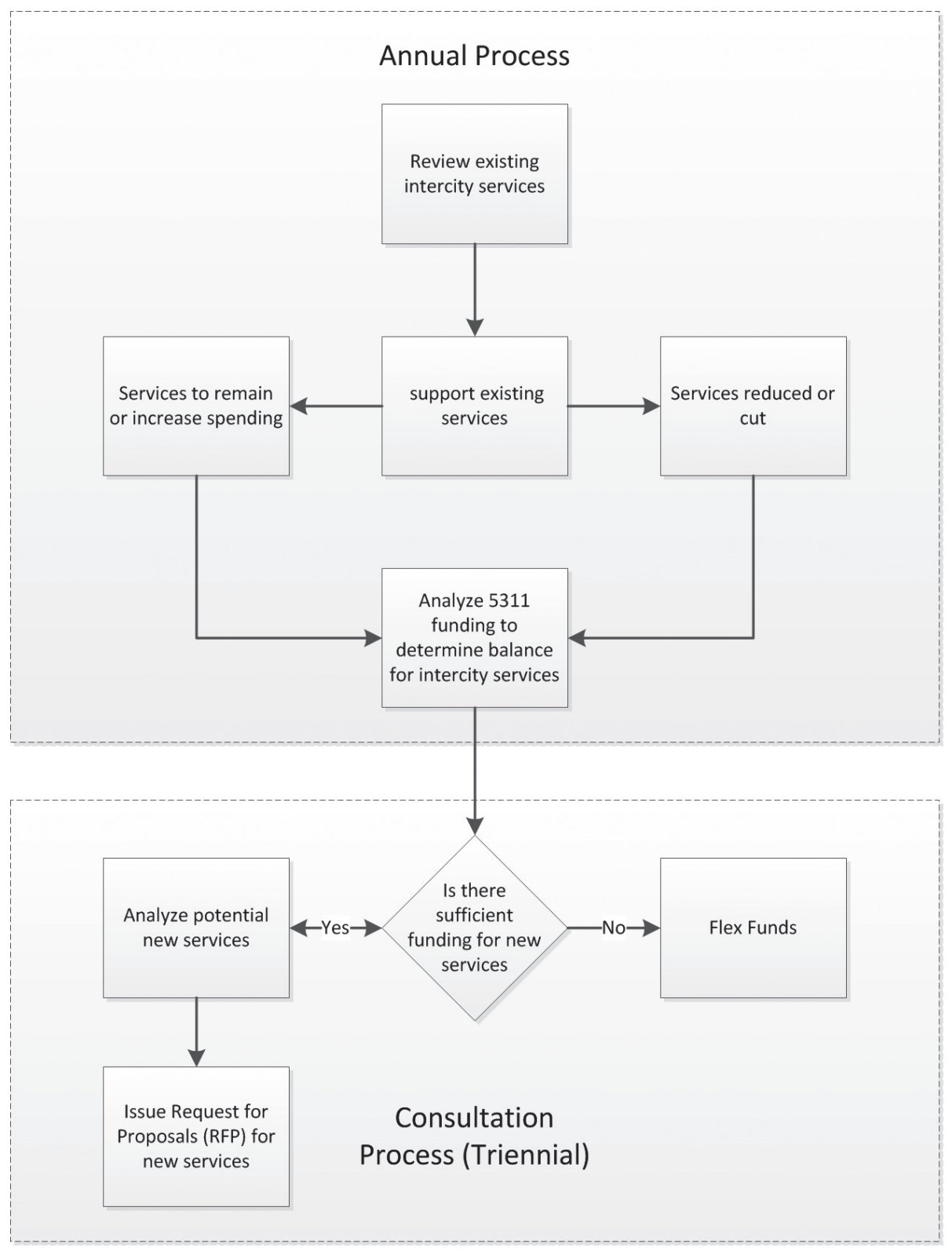

Figure 1. Assessment Methodology 
The savings from those services that receive reduced funding or where funding is cut altogether are returned to the state's $5311(\mathrm{f})$ program fund. This is balanced by additional spending for those services that would receive increased funding for the next fiscal year. New ICB services may be proposed (new routes and/or frequency), which could be funded and, as a result, increase the amount of 5311(f) program funds to be spent. After reviewing the request, the State selects and determines the funding to support existing ICB services. The balance for ICB services is then determined based on the above savings and spending. It should be noted that while FTA guidance discusses a target amount for funding ICB services (15\% of the funds), it does not preclude a state from spending more than $15 \%$ of its Section 5311 funding on ICB services.

\section{Triennial Consultation Process}

If there is sufficient funding in the 5311(f) program based on the annual process, the State goes through a triennial consultation process to determine which new services (routes), if any, to support. This could include funding new routes as well as restoring ICB services that were previously discontinued.

This process first determines whether any cities in Montana with a population of 10,000 or more do not have ICB service. The larger communities are the initial focus of an analysis. If all communities of this size have existing ICB service, an analysis of the next largest communities-population 5,000-9,999-is conducted, followed by an analysis of communities with a population between 2,000 and 4,999 to ascertain whether ICB services or "feeder service" connections to ICB services are available. It is noted that, based on the 2010 U.S. Census (CEIC 2011), Montana has 7 cities with a population of 10,000 or more people, 9 cities with a population between 5,000 and 10,000 people, and 15 cities with a population between 2,000 and 4,999 people. FTA allows funding of "feeder services" that connect small transit operations and ICB carriers. It is likely that any spending of 5311(f) funding in cities/ towns with a population of less than 10,000 people would be for feeder services, which are not subject to the same regulations as other intercity bus services.

Once the initial review of Montana's largest cities is completed, a route analysis is undertaken. The purpose of the route analysis is to identify potential ridership on new or previously-cut routes. Surveys of the general public and local transit agencies can provide information on cities and city pairs that may be in need of ICB services. The list of cities and/or routes from the surveys can be used as a basis to further identify potential routes most in need of ICB services. The State may use different evaluation criteria to assess potential new service routes such as popula- 
tion (density), transit-dependent population, household income, and automobile ownership. Use of a simple evaluation tool to estimate ICB demand based on the populations of locations served is recommended to analyze potential new services. The Toolkit for Estimating Demand for Rural Intercity Bus Services (TCRP 2011) was developed through the Transit Cooperative Research Program (TCRP) program. The inputs for demand forecasting include state, locations (cities), and route length (one-way length in miles). The population will automatically generate for each of the cities selected in the toolkit. However, the toolkit uses population information based on the 2000 Census. With the 2010 Census data available, 2000 Census may not be accurate if there were significant demographic changes between 2000 and 2010 for the proposed route.

Once the route analysis is conducted, MDT consults with local and intercity transit providers to determine which routes would be the most likely to succeed (attract ridership). After the potential new services are identified and analyzed, the State decides on which new routes would be supported with new funding. To get the most service for the least cost, it is recommended that MDT use a Request for Bid (RFB) process. Once MDT has determined which route or routes will be funded, it issues an RFB and transit providers can bid to operate the new services.

\section{Determination of Whether ICB Needs Are Being Met}

As a result of the analysis and consultation process, the state may certify that ICB service needs are adequately being met if no new routes are identified that can provide service at a reasonable cost. It is recommended that MDT use a cost-per-ride and cost-per-mile analysis when determining whether or not to implement (and/ or continue to support) ICB services, including feeder services. It is recommended that the threshold be set at the 85th percentile of costs for similar services. The 85th percentile is used as a basis for several recommendations herein. It is selected as a "reasonable" threshold and is based on the fact that the 85th percentile is used frequently for setting speed limits on many roadways. Therefore, if a new feeder service is planned, it should not be implemented if the projected cost per ride will be more than the cost per ride at the 85th percentile of existing feeder services in Montana.

While there may be requests for new services or routes, MDT could certify that the needs of the state are being met even if there are requests for new services. Montana is a rural and frontier state, with only 31 of its 129 cities and towns having a 
population of 2,000 or more. Due to low population densities, it is recommended that MDT focus support on towns and cities with a population of at least 2,000. At the time of this study, the only cities with a population between 2,000 and 4,999 that do not have ICB service are Colstrip and Red Lodge. This means that 94 percent of Montana's most-populated cities have either direct service from national or regional intercity carriers or feeder services to those carriers. It is recommended that a threshold of 85 percent of Montana's largest cities (currently 26 of 31 cities) be used as a determination of whether the needs are being met. If the state determines that the ICB needs of the state are being met, and fewer than 15 percent of the Section 5311(f) funds need to be expended, it can provide a partial certification.

As presented in the FTA's Circular 9040.1F (FTA 2007), if less than 15 percent of the $5311(\mathrm{f})$ funds will result in needs being adequately met, the State "may submit a "partial" certification for the reminder of the 15 percent and spend only the portion needed to ensure that the intercity bus needs are adequately met." As shown in Table 4, MDT has spent between 9 and 12.7 percent of its FTA Section 5311(f) funding on ICB services for each of the last four State fiscal years, and a partial certification is the most likely outcome in the future.

Table 4. 5311(f) Budget and Funding in Montana

\begin{tabular}{|c|c|c|c|}
\hline State Fiscal Year & $\begin{array}{c}\mathbf{5 3 1 1 ( f )} \\
\text { Funds Available }\end{array}$ & $\begin{array}{c}\mathbf{5 3 1 1}(\mathbf{f}) \\
\text { Obligations }\end{array}$ & Number of Agencies Funded \\
\hline 2008 & $\$ 990,406$ & $\$ 880,955$ & 14 \\
\hline 2009 & $\$ 1,068,791$ & $\$ 898,016$ & 12 \\
\hline 2010 & $\$ 1,127,602$ & $\$ 802,510$ & 8 \\
\hline 2011 & $\$ 1,126,539$ & $\$ 676,268$ & 6 \\
\hline Total & $\$ 4,313,338$ & $\$ 3,217,749$ & \multicolumn{2}{|c|}{} \\
\cline { 1 - 2 } & & \multicolumn{2}{|c|}{}
\end{tabular}

\section{Concluding Remarks}

The literature review and survey found that the prioritization and determination of funds for ICB projects/services include two approaches. States conducting ICB studies to identify routes were found to use an RFP/bid system to award funds. Second, for those states using a grantor/grantee system to award funds, the general process 
of determining funds included three steps: 1 ) submitting proposals by ICB providers, 2) reviewing and/or scoring applications, and 3) determining funds for projects.

The survey also revealed that most rural states have been promoting ICB services. The strategies included press releases on new ICB information, newspaper advertising of routes and schedules, development of transit maps, and cooperative assistance to others.

MDT has a process in place to review transit providers on an annual basis to determine funding levels for the subsequent fiscal year. This research study provided a process that can occur as a triennial process to determine if intercity bus service needs are being met and, if not, a process to determine where service should be implemented (providing sufficient funding exists). Currently, 29 of 31 of the largest cities in Montana have access to intercity bus service. If future analyses yield similar results, it is recommended that MDT use a partial certification so that unspent Section 5311(f) funds can be used for other public transit services.

\section{Acknowledgments}

This research study was supported by the Montana Department of Transportation. The authors thank Kris Christensen, David Jacobs, Audrey Allums, and Doug McBroom of MDT, as well as the other members of the technical panel for their support.

\section{References}

CEIC (Census and Economic Information Center), Montana Department of Commerce. 2011. Census 2010 - Census place population summary (City, Town, CDP). U.S. Census Bureau, Census 2010 PL 94-171.

Federal Transit Administration (FTA). 2007. FTA Circular 9040.1F. Federal Transit Administration, Washington, D.C.

Federal Transit Administration (FTA). 2010. Formula grants for other than urbanized areas (5311). Accessed July 6. http://www.fta.dot.gov/funding/grants/ grants_financing_3555.html

KFH Group, Inc. 2002. Effective approaches to meeting rural intercity bus transportation needs. TCRP Report 79, Federal Transit Administration, Washington, D.C. 
KFH Group, Inc. 2007. Washington State intercity bus service study: Draft final report. Washington State Department of Transportation, Olympia, WA.

KFH Group, Inc. 2010. Task 20: Analysis of rural intercity bus strategy, and Task 25: Evaluate requirements for the utilization of Section 5311(f) funds for intercity bus service. NCHRP Project 20-65, Transportation Research Board, Washington, D.C .

Lindly, J.K. 2009. Intercity bus service study 2007. Tuscaloosa, AL.

Transit Cooperative Research Program (TCRP). 2011. Toolkit for estimating demand for rural intercity bus services. TCRP Report 147, Transportation Research Board, Washington, D.C.

U.S. Census Bureau. 2009. Annual estimates of the resident population for incorporated places in Montana: April 1, 2000 to July 1, 2009. SUB-EST2009-04-30, Population Division, U.S. Census Bureau.

\section{About the Authors}

DR. ZHIRUI YE (yezhirui@seu.edu.cn) is a Professor at Southeast University in China. He was formerly a Research Scientist at the Western Transportation Institute (WTI) at Montana State University. He earned his Ph.D. degree in Transportation Engineering from Texas A\&M University.

DAVID KACK (dkack@coe.montana.edu) is the Program Manager for the Mobility and Public Transportation research area at WTI. He holds a master's Degree in Business Administration and has 12 years of experience specializing in transportation coordination, management, and planning. At WTI, he has worked on several projects to develop and improve rural passenger transportation systems. He served on the team that developed the Montana Coordinated Transportation Handbook and subsequently served as the Principal Investigator for the supplement and update of the handbook. He was also the Principal Investigator for the Real Choices Systems Change Grant project, which focused on improving public and specialized transportation in two communities in Montana. He has helped three communities in Montana start public transportation systems and has an ongoing management role with two of those systems. In 2011, he was the Principal Investigator for the Montana Intercity Bus Service Study, funded by the Montana Department of Transportation. He is a member of the Transportation Research Board's Rural Public and 
Intercity Bus Transportation Committee and has extensive experience working with the public and cultivating multi-agency institutional relationships for the purpose of transportation development.

JAYDEep ChAUdhARI (Jaydeep.chaudhari@coe.montana.edu), AICP, is a Research Scientist with WTI. He is skilled in the fields of transportation planning, safety and operation, policy, intelligent transportation systems (ITS), administration, geographical information system, and architecture, and he helped launch the USDOT Planning Leadership Award-winning transit system, the North Central Montana Transit systems. He is a member of the National Cooperative Highway Research Program road safety project (Design Guidance for High-Speed to Low-Speed Transition Zones for Rural Highways) panel, the Education Group of US-French Cooperation on Mass Transportation: MoU Action Plan (FTA-USDOT), and the Education, Audiovisual and Culture Executive Agency of the European Commission.

LEVI EWAN (Levi.ewan@coe.montana.edu) holds a Bachelor of Science in Civil Engineering degree from Montana State University-Bozeman and is currently enrolled in the master's program for Civil Engineering with a focus on transportation. He is a member of Chi Epsilon, a civil engineering honor society, and the Institute of Transportation Engineers. For his research work at WTI, he has played a key role on public transit and livability projects as wells as co-authoring "Replacing Thermally Sprayed Zinc Anodes on Cathodically Protected Steel Reinforced Bridges." 